\title{
Membentuk Kepribadian Islam melalui Strategi Komunikasi Lembaga Dakwah Kampus (LDK) di STMIK Budi Darma Medan
}

\author{
Fitri Aisyah Ritonga \\ Komunikasi Penyiaran Islam, Universitas Islam Negeri \\ Sumatera Utara, Indonesia \\ Email: fitriaisyahritonga@gmail.com
}

\author{
Ahmad Tamrin Sikumbang \\ Komunikasi Penyiaran Islam, Universitas Islam Negeri \\ Sumatera Utara, Indonesia \\ Email: tamrinsk@yahoo.co.id
}

Article Information

Submited March 02, 2020

Revision June 23, 2020

Accepted July 03, 2020

Published July 30, 2020

\section{Zainun}

Komunikasi Penyiaran Islam, Universitas Islam Negeri

Sumatera Utara, Indonesia

Email: zainundr@gmail.com

\section{Abstract}

Personality as an integration of one's tendency to behave, act and behave. The personality referred to in this case is the personality of honesty and istiqomah which is in accordance with the teachings of Islam and is called the personality of Islam. This study aims to describe the communication strategies of Campus Da'wah Institutions in shaping the Islamic personality of students, as well as the supporting and inhibiting factors of the campus Da'wah Communication strategy in shaping the Islamic personality of STMIK Budi Darma Medan students. The research method used in this study is a qualitative method by analyzing and making interpretation of data found through interviews. The data that has been collected is checked for validity, the data analysis technique starts from reducing the data and making conclusions from the results of the study. The results of this study are that to develop a communication strategy must begin with planning, implementation and of course in this strategy there are supporting and inhibiting factors. The communication strategy of Campus Propagation Institute in shaping the Islamic personality of students by planning and implementing activities that are Islamic by instilling the values of Islamic personality to students. Islamic personality here is the personality of honesty, responsibility, initiative and istiqomah in the daily life of students. Strategies that LDK does include mentoring, recitation and sharing among others. Supporting and inhibiting factors in the Campus Da'wah Institute strategy are good responses from students, while the inhibiting factor is the lack of funds.

\section{Keywords:}

Communication Strategy, Islamic Personality, Campus Da'wah Institut 


\section{Abstrak}

Kepribadian sebagai integrasi dari kecenderungan seseorang dalam bersikap, bertindak dan berperilaku. Kepribadian islam merupakan kepribadian tentang kejujuran, tanggungjawab, inisiatif dan istiqomah yang sesuai dengan ajaranajaran Islam. Penelitian ini bertujuan untuk mengetahui strategi komunikasi Lembaga Dakwah Kampus dalam membentuk kepribadian Islam mahasiswa, serta faktor pendukung dan penghambat dari strategi komunikasi Lembaga Dakwah Kampus. Metode penelitian yang digunakan dalam penelitian ini adalah metode kualitatif dengan menganalisis dan membuat interpretasi data yang ditemukan melalui hasil wawancara. Data yang telah dikumpulkan diperiksa keabsahannya, teknik analisa data dimulai dari mereduksi data dan membuat simpulan hasil penelitian. Hasil dari penelitian ini mendeskripsikan strategi komunikasi Lembaga Dakwah Kampus dalam membentuk kepribadian Islam mahasiswa. Bentuk-bentuk strategi komunikasi adalah komunikasi antar personal dan komunikasi tidak langsung yaitu dakwah berbasis materi dan dakwah berbasis media. Faktor pendukung dalam strategi Lembaga Dakwah Kampus ini yaitu respon yang baik dari mahasiswa, pengurus LDK memiliki potensi yang lebih, LDK Al-Hayyan memiliki susunan struktur anggota keorganisasian yang jelas sedangkan faktor penghambatnya yaitu masalah kurangnya dana dalam program LDK, kurangnya waktu untuk bersosialisasi dan semangat anggota LDK yang menurun.

Kata kunci:

Strategi Komunikasi, Kepribadian Islam, Lembaga Dakwah

\section{PENDAHULUAN}

Kepribadian sebagai unsur dari akal dan jiwa manusia yang menentukan tingkah laku dan tindakan seseorang. Kepribadian yang berbentuk dinamis merupakan kepribadian seseorang seperti perilaku yang dapat berubah-ubah karena beberapa faktor dari pembelajaran, pengalaman dan pendidikan. Perkembangan kepribadian yang dinamis dimaksud jika seseorang terus menambah pengetahuannya dan terus belajar, maka kepribadiannya akan semakin matang. Pada umumnya telah banyak ditemukan tingah laku atau kepribadian seseorang yang berubah-ubah, contohnya kepribadian pada mahasiswa zaman sekarang (Yusuf, 2015). Apabila mahasiswa melakukan sesuai dengan koridornya sebagai kaum intelektual yang beretika maka bisa disebut dengan keteladanan.

Moral mahasiswa terlihat dari penampilan dari kepribadiannya, contohnya seperti ucapan, tindakan, cara bergaul dan cara berpakaian (Sukarta, 2018). Solusi degradasi moral mahasiswa memerlukan peran mahasiswa sendiri untuk mengatasi dan memperbaiki segala persoalan yang dihadapi untuk menjadi mahasiswa yang mempunyai kepribadian jujur dalam berucap dan istiqomah dalam berbuat baik. Membutuhkan pencerahan untuk solusi yang menjadi lebih baik lagi, salah satunya dengan sebuah aspek pendidikan. Dengan adanya aspek pendidikan tentu akan diajarkan bagaimana cara memahami dan bertingkah laku yang sesuai dalam kehidupan. Pendidikan akan memberikan bekal yang akan diamalkan untuk mahasiswa yang beradab. Adapun pendidikan yang dimaksud tidak hanya pendidikan yang secara umum, tetapi pendidikan mengenai agama Islam (Alam, 2016). 
Kepribadian ataupun tingkah laku mahasiswa terbentuk sejak masih anak-anak karena adanya pengaruh-pengaruh yang dapat menimbulkan gambaran dari seseorang. Kepribadian yang dimaksud dalam hal ini adalah kepribadian tentang kejujuran dan istiqomah yang sesuai dengan ajaran-ajaran Islam dan disebut dengan kepribadian Islam. Begitu pula dengan mahasiswa yang duduk di bangku perkuliahan yang tidak paham agama, bisa saja mahasiswa tersebut dengan mudah membohongi dosennya sendiri, bertengkar dengan temannya, menyontek disaat ujian dan tidak menutup aurat bagi mahasiswi padahal hal tersebut juga bermasalah dalam hukum Islam. Hal tersebut bisa terjadi karena kurangnya beribadah dalam sholat dan kurangnya pemahaman terhadap ayat-ayat Al Quran sehingga timbulnya kegiatan yang tidak baik. (Wildan, 2015)

Konteks dalam kepribadian kejujuran menjadi penting untuk diterapkan pada setiap mahasiswa, misalnya ketika pelaksanaan ujian, mahasiswa mampu untuk jujur dalam mengerjakannya, karena sadar akan hal yang tidak jujur. Terdapatnya warung kejujuran di kampus yang mengharuskan mahasiswa jujur dalam melakukan pembelian dan pembayaran dengan diri sendiri. Karena pada dasarnya warung kejujuran adalah warung yang hanya menyediakan makanan saja tanpa ada yang mengawasi atau tanpa adanya penjual. Setiap pembeli yang ingin membeli sesuatu bisa mengambil yang dibutuhkannya dengan sendiri dan meletakkan pembayarannya sendiri ke kotak pembayaran yang telah disediakan. Hal tersebut mengharuskan mahasiswa untuk menanamkan kepribadian kejujuran pada diri sendiri. (Setiawan, 2015)

Lembaga Dakwah Kampus (LDK) mempunyai peranan yang begitu penting pada setiap kampus. Kesuksesan Lembaga tersebut bisa ditentukan oleh adanya kualitas yang terdapat pada para aktivis dakwahnya. Perguruan Tinggi yang gunanya sebagai tongkat perjuangan bagi generasi muda untuk perjuangan agama dan negara, bukan hanya tempat pembinaan jasmani tetapi juga untuk pembinaan rohani. Oleh karena itu, kampus-kampus yang ada telah menyediakan sarana yang berupa masjid untuk pembinaan keagamaan yang berperan penting dalam mental para mahasiswa. Masjid kampus merupakan sarana yang paling sering digunakan oleh lembaga dakwah kampus untuk meningkatkan spiritual mahasiswa dengan kajian keislaman dan perbincangan tentang keislaman seperti ceramah dan diskusi. Para pemuda yang menjadi aktivis dengan bersemangat kembali kepada tradisi Islam untuk istiqomah di jalan Allah dimulai dengan cara berpakaian sampai pola-pola perilaku dengan cara yang Islami. (Samsu \& Mansur, 2019)

Pembinaan agama dalam kegiatan dakwah di kampus suatu urusan untuk membimbing, mengembangkan dan menyempurnakan dalam segala perilaku dari segi akidah, ibadah dan akhlak manusia. Semakin tinggi keimanan dan ketakwaannya seseorang, maka akan semakin baik juga sikap dan perilakunya. Pembinaan yang dilaksanakan Lembaga Dakwah Kampus merupakan suatu pembinaan individu buat mahasiswa yang berupa halaqoh atau bentuk kegiatan lainnya. Dengan melaksanakan kegiatan-kegiatan yang berlandaskan pada ajaranajaran Islam akan mengubah dan membentuk menjadi kepribadian yang baik bagi mahasiswa. (Prayogi, 2019)

Adapun tujuan LDK Al-Hayyan ini untuk memiliki program mencetak aktivis dakwah kampus yang berkepribadian Islam, berintegritas tinggi yang mampu membuat mahasiswa yang awalnya tidak memiliki kepribadian Islami menjadi kepribadian Islami. Indikator dalam pembentukan kepribadian Islam mahasiswa di STMIK Budi Darma Medan, sebagai berikut: pertama, aspek kognifif yaitu melakukan mentoring dan kajian dengan memberikan atau menceritakan kisah-kisah teladan dari kehidupan para Nabi dan perjuangan para sahabat Nabi, 
melakukan pengajian setiap hari Jumat dan dilakukan setiap dua minggu sekali, mengikuti kegiatan di luar kampus seperti outbound, guna untuk menumbuhkan rasa tanggung jawab dan kerja sama antar tim. Kedua, aspek psikomotorik yaitu sholat dhuha, tadarus al-quran, membaca al-quran dan mentoring. Ketiga, aspek afektif yaitu berpakaian rapi dan menutup aurat dan berprilaku sopan dan santun.

Pergerakan dakwah yang dilakukan Lembaga Dakwah Kampus bersifat dinamis dengan sistem keorganisasian dan memodifikasi tampilan gaya untuk dakwah merupakan realitas yang sudah terjadi di dalam Lembaga Dakwah Kampus Al-Hayyan Budi Darma Medan. Lembaga Dakwah Kampus Al-Hayyan telah memberikan perubahan yang cukup besar dalam membentuk dan mempengaruhi mahasiswa dengan metode dakwah yang dianutnya. Metode yang diikuti tentu sesuai dengan metode dakwah Rasul dan sesuai dengan nilai-nilai Islam. Namun demikian dalam proses dakwah yang dilaksanakan, Lembaga Dakwah Kampus AlHayyan menghadapi berbagai macam karakter dari objek dakwahnya seperti status sosial dan latar belakang yang berbeda-beda, maka dari itu perlu kiranya pengambilan peran dalam seorang da'i untuk membantu mahasiswa dalam membentuk kepribadiannya dalam memenuhi kebutuhannya sebagai pelajar dan menyelesaikan masalahnya.

Adapun tujuan LDK Al-Hayyan ini untuk mencetak aktivis dakwah kampus yang berkepribadian Islam, berintegritas tinggi yang mampu membuat mahasiswa yang awalnya tidak memiliki kepribadian Islami menjadi kepribadian Islami. Kegiatan yang dilaksanakan oleh Lembaga Dakwah Kampus (LDK) tersebut menggunakan teori manajemen yang dapat diartikan usaha untuk mencapai tujuan yang dilakukan oleh seorang pemimpin dan diikuti oleh bagian-bagian dari anggotanya. Keberhasilan dari Lembaga Dakwah Kampus (LDK) merupakan dari satu indikator yang sebagaimana untuk meningkatkan wawasan keislaman bagi mahasiswa yang ikut tergabung dalam lembaga tersebut dan juga seluruh mahasiswa pada umumnya.

Metode yang diikuti tentu sesuai dengan metode dakwah Rasul dan sesuai dengan nilai-nilai Islam. Namun demikian dalam proses dakwah yang dilaksanakan, Lembaga Dakwah Kampus Al-Hayyan menghadapi berbagai macam karakter dari objek dakwahnya seperti status sosial dan latar belakang yang berbeda-beda, maka dari itu perlu kiranya pengambilan peran dalam seorang da'i untuk membantu mahasiswa dalam membentuk kepribadiannya dalam memenuhi kebutuhannya sebagai pelajar dan menyelesaikan masalahnya.

\section{Metode}

Penelitian ini merupakan penelitian studi kasus (case study) yang mempelajari tentang latar belakang dari Lembaga Dakwah Kampus (LDK) Al-Hayyan STMIK Budi Darma Medan. Teknik dalam menentukan informan dalam penelitian ini menggunakan teknik purposive non random. Di mana peneliti yang menentukan informan dengan cara menetapkan ciri-ciri yang khusus sesuai dengan tujuan penelitian agar dapat menjawab permasalahan dari penelitian. Informan dalam penelitian ini adalah pihak Lembaga Dakwah Kampus STMIK Budi Darma Medan.

Adapun informan dalam wawancara yang dipilih dalam penelitian ini sebagai berikut: sekretaris umum LDK al-hayyan, koordinator akhwat LDK al-hayyan, bidang kaderisasi LDK al-hayyan merupakan penjaga jalannya roda organisasi sesuai dengan amanah yang telah diberikan, koordinator humas dan syiar LDK al-hayyan, sekretaris dana dan usaha LDK alhayyan, anggota LDK al-hayyan yang ikut berpartisipasi untuk mensukseskan kegiatan yang dilaksanakan dan juga bisa sebagai pengkritik atau memberi masukan dari kegiatan yang 
dilaksanakan, mahasiswa STMIK Budi Darma Medan dari pihak yang bukan dari anggota lembaga dakwah kampus sebagai pemberi saran dan masukan dari setiap kegiatan yang dilaksanakan oleh anggota lembaga dakwah kampus.

Sumber data dalam penelitian ini ada dua pengumpulan data, pertama data primer sebagai data asli yang didapatkan langsung dari sumber datanya. Data ini didapat dari observasi dan wawancara dengan ketua LDK Al-hayyan Budi Darma Medan. Kedua, data sekunder sebagai data pendukung dan pelengkap dalam penulisan. Data tersebut berupa laporan penelitian, jurnal, dan literatur-literatur yang relevan dengan penelitian.

Teknik pengumpulan data dari sumber primer maupun sekunder, menggunakan teknik sebagai berikut: pertama peneliti mengumpulkan data dengan cara melakukan pencatatan terhadap kejadian-kejadian yang terjadi, perilaku dan objek-objek yang dilihat. Observasi dapat diklasifikasikan dalam berbagai bentuk, mempunyai berbagai fungsi yang sesuai dengan tujuan dan metode penelitian yang digunakan. Peneliti melakukan observasi melalui penglihatan perilaku dan bagaimana keadaan mahasiswa melalui pendengaran pada tempat yang diteliti. Kedua, peneliti menggunakan teknik wawancara setelah selesai melakukan observasi pada kejadian di tempat tersebut. Adapun beberapa pertanyaan yang menjadi proses pada saat wawancara, yaitu: penyusunan materi atau pesan yang akan disampaikan Organisasi LDK dalam komunikasi dengan mahasiswa pada saat berkegiatan, metode yang diterapkan LDK dalam berkomunikasi, media yang digunakan LDK yang mendukung proses komunikasi dan pelaksana strategi komunikasi LDK untuk meningkatkan pengamalan agama terhadap mahasiswa. Dalam pelaksanaannya, peneliti melakukan wawancara dengan narasumber dari ketua umum LDK dan salah satu dari anggota LDK sebagai penguat data.

\section{Hasil dan Pembahasan}

Strategi Komunikasi LDK dalam Membentuk Kepribadian Islam

\section{Mahasiswa}

STMIK Budi Darma Medan telah banyak menyelenggarakan berbagai macam organisasi yang dikelola oleh mahasiswa STMIK Budi Darma dan organisasi-organisasi tersebut telah mendapat persetujuan dari yayasan atau ketua STMIK Budi Darma. Salah satu organisasi yang eksis adalah Lembaga Dakwah Kampus (LDK) Al-Hayyan yang merupakan organisasi kampus yang bergerak dalam bidang Keislaman yang bekerja sama dengan unit kegiatan antar kampus. Organisasi ini terbentuk melalui Unit Kegiatan Mahasiswa (UKM). LDK Al-Hayyan STMIK Budi Darma Medan didirikan di Medan, 12 September 2010 yang bermarkas di Musholla Gedung C lantai dasar STMIK Budi Darma Medan. Organisasi yang dipelopori oleh beberapa mahasiswa muslim STMIK Budi Darma Medan yang peduli dengan perkembangan hidup beragama di kampus.

Strategi komunikasi dalam Lembaga Dakwah Kampus merupakan proses untuk menentukan perencanaan dalam berbagai situasi agar tujuan dari dakwah tercapai secara maksimal. Di dalam perencanaan untuk menyusun strategi komunikasi dalam kelompok, tentu adanya bentuk agar strategi komunikasi tersebut dapat tersampaikan kepada target. Adapun bentuk-bentuk strategi komukasi yang digunakan Lembaga Dakwah Kampus AlHayyan yaitu:

1. Bentuk komunikasi antar personal

Pada kegiatan yang dilaksanakan oleh organisasi LDK Al-Hayyan mengenai program pembinaan dan mentoring pada mahasiswa STMIK Budi Darma Medan mengenai Islam, 
sebagian mahasiswa tentang pengetahuan Islam masih sangat dangkal, kecuali mereka yang dulu pernah bersekolah di pesantren. Adapun setelah mahasiswa yang telah mengikuti Pembinaan dan Mentoring menjadi banyak tahu mengenai tauhid, ibadah dan pengetahuan mengenai adab pergaulan sehari-hari. Maka dari itu, agama sangat berperan dalam mempengaruhi tindakan, ucapan dan pola pikir dari setiap muslim. Adapun yang menjadikannya sarana untuk men-charge iman dari setiap muslim adalah dengan cara pembinaan dakwah.

Komunikasi antar personal merupakan komunikasi yang dilakukan secara tatap muka dengan setiap orang dan orang tersebut langsung memberikan reaksi. Bentuk komunikasi antar personal yang digunakan Lembaga Dakwah Kampus Al-Hayyan ada yang secara langsung dan ada yang tidak secara langsung. Komunikasi secara langsung dilakukan dengan tatap muka untuk penyampaian berita informasi. Bentuk strategi komunikasi yang dilaksanakan LDK AlHayyan meliputi pengembangan dakwah dengan metode halaqoh, kepedulian terhadap sesama dan dakwah berbasis media. Salah satu bentuk dari strateginya adalah strategi rasional yang merupakan dakwah dengan metode yang melalui pada aspek akal pikiran. Strategi ini meminta para dakwah untuk berpikir dan memberikan pelajaran.

Strategi Komunikasi antar personal yang dilakukan oleh LDK ini berupa holaqoh yang dilakukan rutin satu minggu sekali dengan tutor masing-masing dalam setiap kelompok. Satu tutor akan membimbing 12 mahasiswa. Tutor berasal dari mahasiswa senior LDK atau dari luar kampus yang ditunjuk oleh kepengurusan LDK tersebut. Komunikasi antar personal ini dimaksudnya agar terjadi komunikasi yang intens antara tutor dengan bimbingannya agar tercapai kemajuan yang signifikan.

\section{Bentuk Komunikasi Tidak Langsung}

a. Dakwah Berbasis Materi

LDK Al-Hayyan melaksanakan dakwah berbasis pada materi dengan cara mengadakan kegiatan kajian rutin secara online dengan menyampaikan materi-materi keislaman yang akan menambah wawasan dan meningkatkan iman mahasiswa sesuai dengan ajaran-ajaran Islam secara online. Kajian berbasis Online dilakukan agar bisa terlaksanakannya forum tanya jawab buat umum, hal ini juga tidak hanya memudahkan bagi mahasiswa di lingkungan kampus tetapi juga memudahkan bagi pihak umum yang di mana pun berada. Adapun materi yang diambil pada kajian umumnya bertema tentang akidah dan wawasan keislaman lainnya yang berfokus pada para pemuda dengan konsep hijrah agar mahasiswa lebih semangat dan mudah untuk memahaminya. Pemateri dalam mengisi kajian bisa dari dosen yang ada di kampus dan juga ada pemateri dari luar yang diundang.

b. Dakwah berbasis media

Berdakwah melalui media sosial memberikan kesan yang lebih efektif karena di mana pun mahasiswa berada dengan menggunakan handphone mereka tentu sudah bisa mengikuti dakwah yang bertema motivasi. LDK Al-Hayyan telah menerapkan berdakwah dengan melalui media dengan tujuan untuk memberikan solusi terhadap masalah yang berkaitan di dalam kampus, masalah yang berdampak hal yang negatif yang dapat merusak akhlak, moral dan perilaku mahasiswa. Adapun media sosial yang digunakan oleh pihak LDK Al-Hayyan yaitu blog, instagram dan facebook dengan memberikan kata-kata ataupun video motivasi yang sudah didesain dan informasi yang berkaitan dengan kegiatan-kegiatan yang dilaksanakan LDK Al-Hayyan. Berdakwah melalui berbagai media sosial dan menyebarkan informasi-informasi yang bermanfaat seperti mendesain video atau film-film yang berikan dakwah dan akan 
Fitri Aisyah Ritonga; Ahmad Tamrin Sikumbang; Zainun (Membentuk Kepribadian Islam melalui...)

dibagikan oleh pihak LDK Al-Hayyan ke semua sosial media. Berdakwah yang menggunakan media tentu akan memberikan informasi-informasi yang terbaru mengenai Islam kepada semua yang mengikuti media-media dari pihak LDK Al-Hayyan.

Melalui media baik media online, tidak hanya untuk menyampaikan dakwah tetapi juga digunakan untuk mempromosikan kegiatan yang akan direncanakan oleh Lembaga Dakwah Kampus agar seluruh mahasiswa kampus bisa tau dan dapat menghadiri kegiatan yang rencanakan dengan informasi yang dimuat di sosial medan Lembaga Dakwah Kampus Al-Hayyan. Adapun informasi yang dimuat di sosial media berupa gambar yang didesain dengan menarik mungkin, itulah strategi yang digunakan oleh Lembaga Dakwah Kampus AlHayyan untuk memberikan informasi-informasi terkait Lembaga Dakwah Kampus Al-Hayyan. Di bawah ini adalah gambar-gambar berupa informasi dari perencanaan kegiatan yang dilakukan Lembaga Dakwah Kampus Al-Hayyan yang diposting pada sosial Media akun official Lembaga Dakwah Kampus Al-Hayyan.

Bentuk komunikasi yang digunakan Lembaga Dakwah Kampus Al-Hayyan untuk membentuk kepribadian mahasiswa STMIK Budi Darma Medan yaitu bentuk kegiatan yang bernama open house yang di laksanakan oleh anggota Lembaga Dakwah Kampus Al-Hayyan STMIK Budi Darma Medan. Bentuk komunikasi tersebut selalu disebarkan melalui sosial media yang dimiliki oleh Lembaga Dakwah Kampus Al-Hayyan, agar seluruh mahasiswa mengetahui informasi tersebut.

Secara umum strategi komunikasi yang dilaksanakan oleh LDK Al-Hayyan adalah dengan memberdayakan keterampilan dan kreativitas dalam berdakwah. Adapun kegiatan yang dilakukan bernuansa Islami seperti pada hari-hari penting bagi umat Islam atau kegiatankegiatan yang menghubungkan tali silaturahmi sesama umat Islam, adapun kegiatannya sebagai berikut:

Tabel 1. Tema Kajian dan Nama Pemateri

\begin{tabular}{|c|c|c|c|c|}
\hline No. & Tema Kajian & Pemateri & Waktu & Tempat \\
\hline 1. & Be A Great Muslimah & $\begin{array}{l}\text { Fitrah Naraidillah } \\
\text { Nst dan Sonya Ma- } \\
\text { linda Harahap }\end{array}$ & $\begin{array}{l}\text { Jumat, } 05 \text { Juli } \\
\text { 2019, } 14.00 \text { WIB - } \\
\text { selesai }\end{array}$ & $\begin{array}{l}\text { Mushollah Lt.1 STMIK Budi } \\
\text { Darma Medan }\end{array}$ \\
\hline 2. & $\begin{array}{l}\text { Nothing be some- } \\
\text { thing }\end{array}$ & Suginem,SE,M.Ak & $\begin{array}{l}\text { Jumat, } 11 \text { Novem- } \\
\text { ber 2019, } 13.00- \\
\text { selesai }\end{array}$ & $\begin{array}{l}\text { Mushollah Lt.1 STMIK Budi } \\
\text { Darma Medan }\end{array}$ \\
\hline 3. & Give me a power & Dwika Assrani,S.Kom & $\begin{array}{l}\text { Jumat, } 08 \text { Novem- } \\
\text { ber 2019, } 13.30 \text { - } \\
\text { selesai }\end{array}$ & $\begin{array}{l}\text { Mushollah Lt.1 STMIK Budi } \\
\text { Darma Medan }\end{array}$ \\
\hline 4. & $\begin{array}{l}\text { Sedih boleh, putus } \\
\text { asa jangan }\end{array}$ & Yuli Efriani & $\begin{array}{l}\text { Jumat, } 23 \text { Oktober } \\
\text { 2019, } 13.30 \text { - sele- } \\
\text { sai }\end{array}$ & $\begin{array}{l}\text { Mushollah Lt.1 STMIK Budi } \\
\text { Darma Medan }\end{array}$ \\
\hline 5. & $\begin{array}{l}\text { Percuma ganteng ka- } \\
\text { lau gak ngaji }\end{array}$ & $\begin{array}{l}\text { Ust Alan Bangun } \\
\text { Siregar dan Ust Ar- } \\
\text { mansyah Ritonga }\end{array}$ & $\begin{array}{l}23 \text { November } \\
2019,21.30 \text { (Ba'da } \\
\text { Isya) }\end{array}$ & Masjid Ubudiyah \\
\hline 6. & $\begin{array}{l}\text { Menerapkan suri tau- } \\
\text { ladan Rasullah SAW } \\
\text { di era revolusi } 4.0\end{array}$ & Ust Ismudin Bancin & $\begin{array}{l}\text { Jumat, } 29 \text { Novem- } \\
\text { ber 2019, } 13.45 \\
\text { WIB (Ba'da Dz- } \\
\text { uhur) }\end{array}$ & $\begin{array}{l}\text { Green Hall Aula Lantai } 7 \text { ST- } \\
\text { MIK Budi Darma Medan }\end{array}$ \\
\hline 7. & $\begin{array}{l}\text { Mewujudkan gener- } \\
\text { asi milenial dengan } \\
\text { mengikuti perjuan- } \\
\text { gan Rasullah }\end{array}$ & $\begin{array}{l}\text { Ust Ahmad Fauzi Na- } \\
\text { sution }\end{array}$ & $\begin{array}{l}\text { Sabtu, } 13 \text { April } \\
\text { 2019, 13.30 WIB }\end{array}$ & STMIK Budi Darma Medan \\
\hline
\end{tabular}


KOMUNIKA: Jurnal Dakwah dan Komunikasi, 14 (1), April 2020

Fitri Aisyah Ritonga; Ahmad Tamrin Sikumbang; Zainun (Membentuk Kepribadian Islam melalui...)

\begin{tabular}{|l|l|l|l|l|}
\hline 8. & Hijrah dan Ukhuwah & $\begin{array}{l}\text { Azwar Akbar Mar- } \\
\text { bun }\end{array}$ & $\begin{array}{l}\text { Sabtu, 05 Okto- } \\
\text { ber 2019, 08.15 } \\
\text { WIB-selesai }\end{array}$ & $\begin{array}{l}\text { Green Hall Aula Lantai 7 ST- } \\
\text { MIK Budi Darma Medan }\end{array}$ \\
\hline 9. & $\begin{array}{l}\text { Kajian akbar mas- } \\
\text { yarakat STMIK Budi } \\
\text { Darma }\end{array}$ & $\begin{array}{l}\text { Ust Tho'at Stiadhy, } \\
\text { S.Pd.I }\end{array}$ & $\begin{array}{l}\text { Jumat, 12 Juli } \\
\text { 2019, 14.00 WIB - } \\
\text { selesai }\end{array}$ & $\begin{array}{l}\text { Lantai 2, Ruang Donor Dar- } \\
\text { ah STMIK Budi Darma Med- } \\
\text { an }\end{array}$ \\
\hline 10. & $\begin{array}{l}\text { Hijrah yuk !! Sendiri } \\
\text { berat makanya rame- } \\
\text { rame }\end{array}$ & $\begin{array}{l}\text { Azwar Akbar Mar- } \\
\text { bun }\end{array}$ & $\begin{array}{l}\text { Sabtu, 05 Oktober } \\
\text { 2019, 08.15 WIB - } \\
\text { selesai }\end{array}$ & $\begin{array}{l}\text { Green Hall Aula Lantai 7 ST- } \\
\text { MIK Budi Darma Medan }\end{array}$ \\
\hline
\end{tabular}

Dari tema-tema materi kajian yang tertera di atas merupakan materi yang sangat ringan dan bisa dikaitkan dengan permasalahan sehari-hari di dunia mahasiswa. Kajian dilaksanakan bertujuan untuk memberikan kesadaran dan memberikan semangat kepada mahasiswa sesuai dengan pemahaman tauhid yang sesuai dengan ajaran-ajaran agama Islam dan untuk memberikan benteng kepada generasi pemuda-pemuda Islam yang memiliki pemikiran-pemikiran yang sudah menyimpang dari syariat Islam.

Menurut Sekretaris Umum LDK Al-Hayyan strategi komunikasi dakwah yang dilaksanakan oleh LDK Al-Hayyan adalah dengan memberdayakan keterampilan dan kreativitas dalam berdakwah. Adapun kegiatan yang dilakukan bernuansa Islami seperti pada hari-hari penting bagi umat Islam atau kegiatan-kegiatan yang menghubungkan tali silaturahmi sesama umat Islam, adapun kegiatannya sebagai berikut (Angkat, 2020):

Tabel 2. Kegiatan dan Tema Kajian

\begin{tabular}{|c|c|c|c|c|}
\hline No. & Tema Kajian & Pemateri & Waktu & Tempat \\
\hline 1. & $\begin{array}{l}\text { Open house spe- } \\
\text { sial nobar negeri } 5 \\
\text { menara }\end{array}$ & $\begin{array}{l}\text { Pemuda Islam dam- } \\
\text { baan umat, apakah } \\
\text { itu kamu? }\end{array}$ & $\begin{array}{l}\text { Sabtu, } 25 \text { Novem- } \\
\text { ber 2017, 09.00- } \\
\text { selesai }\end{array}$ & $\begin{array}{l}\text { Green Hall Aula Lantai } 7 \text { ST- } \\
\text { MIK Budi Darma Medan }\end{array}$ \\
\hline 2. & $\begin{array}{l}\text { Peringatan maulid } \\
\text { Nabi Muhammad } \\
\text { SAW } 1440 \text { Hijriah }\end{array}$ & & $\begin{array}{l}\text { Jumat, } 14 \text { Desem- } \\
\text { ber 2018, } 13.30 \\
\text { WIB }\end{array}$ & $\begin{array}{l}\text { Green Hall Aula Lantai } 7 \text { ST- } \\
\text { MIK Budi Darma Medan }\end{array}$ \\
\hline 3. & IFTHOR & $\begin{array}{l}\text { Ramadhan ceria, Ra- } \\
\text { madhan karem }\end{array}$ & $\begin{array}{l}\text { Jumat, } 24 \text { Mei } \\
\text { 2019, 17.00 WIB }\end{array}$ & $\begin{array}{l}\text { Green Hall Aula Lantai } 7 \text { ST- } \\
\text { MIK Budi Darma Medan }\end{array}$ \\
\hline 4. & $\begin{array}{l}\text { Isra' Mi'raj Nabi be- } \\
\text { sar Muhammad SAW } \\
1440 \mathrm{H}\end{array}$ & $\begin{array}{l}\text { Mewujudkan gener- } \\
\text { asi millenial dengan } \\
\text { mengikuti perjala- } \\
\text { nan Rasullah }\end{array}$ & $\begin{array}{l}\text { Sabtu, } 13 \text { April } \\
\text { 2019, 13.30 WIB }\end{array}$ & $\begin{array}{l}\text { Pelataran Kampus } 1 \text { STMIK } \\
\text { Budi Darma Medan }\end{array}$ \\
\hline 5. & $\begin{array}{l}\text { KURMA Kumpul } \\
\text { Bareng Ramadhan }\end{array}$ & & $\begin{array}{l}\text { Jumat, } 24 \text { Mei } \\
\text { 2019, 17.00 WIB }\end{array}$ & $\begin{array}{l}\text { Pelataran Kampus } 1 \text { STMIK } \\
\text { Budi Darma Medan }\end{array}$ \\
\hline 6. & $\begin{array}{l}\text { Temu ramah sila- } \\
\text { turahmi akhwat Budi } \\
\text { Darma }\end{array}$ & $\begin{array}{l}\text { Ayo eratkan lagi } \\
\text { ukhuwah persauda- } \\
\text { raan kita uktifillah. }\end{array}$ & $\begin{array}{l}\text { Jumat, } 15 \text { Novem- } \\
\text { ber 2019, } 13.30 \\
\text { WIB }\end{array}$ & $\begin{array}{l}\text { Mushollah Lt.1 STMIK Budi } \\
\text { Darma Medan }\end{array}$ \\
\hline 7. & Sahur on the road & $\begin{array}{l}\text { Salurkan bantuan } \\
\text { terbaik untuk sauda- } \\
\text { ra kita di jalan }\end{array}$ & $\begin{array}{l}\text { Selasa, } 14 \quad \text { Mei } \\
2019\end{array}$ & $\begin{array}{l}\text { Pelataran Kampus } 1 \text { STMIK } \\
\text { Budi Darma Medan }\end{array}$ \\
\hline
\end{tabular}

Dalam kegiatan-kegiatan yang di atas bertujuan untuk meningkatkan tali silaturahmi antara sesama umat Islam. Peran LDK Al-Hayyan sangat terus menjaga tali silaturahmi dengan menggunakan keterampilan dalam waktu dan kreativitas. Seperti yang telah dikatakan oleh Rizka Fitriyana salah satu koordinator akhwat LDK Al-Hayyan bahwa dengan mengikuti 
KOMUNIKA: Jurnal Dakwah dan Komunikasi, 14 (1), April 2020

Fitri Aisyah Ritonga; Ahmad Tamrin Sikumbang; Zainun (Membentuk Kepribadian Islam melalui...)

kegiatan-kegiatan yang di laksanakan oleh pihak LDK mahasiswa akan mengetahui apa yang belum diketahui sebelumnya dan mahasiswa juga menjadi tahu cara berteman, menjalin silaturahmi antar sesama dan dapat berperilaku yang baik (Fitriyana, 2020).

\section{Faktor Pendukung dan Penghambat dari Strategi Komunikasi LDK}

Lembaga Dakwah Kampus STMIK Budi Darma Medan yang telah mempunyai struktur terdiri dari beberapa bidang dari tugasnya masing-masing yang telah terorganisir dan dianggap kompeten untuk mengatur tugas yang sesuai dengan bidangnya dan berharap menjalankan tugasnya sesuai bidang masing-masing. Pemilihan struktur pada organisasi Lembaga Dakwah Kampus sesuai dengan kemampuan yang dimiliki dan menjalankan kerja sama agar tercapai tujuan yang telah diterapkan dengan bersama. Berdasarkan kondisi yang beragam dari pengamalan agama mahasiswa LDK Al-Hayyan Budi Darma Medan yang bisa dikaitkan dengan sikap yang religius. Maka dapat dievaluasi terhadap kondisi yang beragam dari pengamalan agama mahasiswa untuk menjawab sudah sejauh mana sikap yang religius yang dimiliki oleh mahasiswa. Adapun sikap, nilai dan norma LDK Al-Hayyan Budi Darma Medan sebagai berikut:

Pertama, sikap religius dalam moral. Moral yang dimaksud yaitu keterikatan dengan aturan-aturan yang bersumber pada ajaran agama. Keterikatan tersebut akan memberikan pengaruh pada sikap yang terdapat pada nilai-nilai kehidupan yang akan menjadi pilihan utama dalam menentukan berbagai pilihan yang ada di kehidupan sehari-hari dan untuk menetapkan suatu tindakan. Sikap yang dimaksud disini adalah moral tentang kejujuran dan istiqomah. Sikap religius dan moral contohnya dari mahasiswa yang perempuan pada saat mereka pergi untuk kuliah, mereka menggunakan pakaian yang sopan dan rapi, tetapi pada saat mereka pulang dari kuliah atau pada saat pergi keluar dari kampus, pakaian mereka berubah menjadi ketat dan bahkan ada yang tidak menggunakan hijab lagi. Hal di atas sudah menunjukkan bahwa lingkungan dan pergaulan cepat saja memberikan perubahan dan faktor bagi mahasiswa. Bagi mahasiswa tidak mudah untuk beradaptasi dan menerapkan hal-hal yang sudah menjadi kebiasaan yang dilakukan. Kepribadian yang dimiliki oleh mahasiswa berbeda-beda, kepribadian bisa berubah karena faktor lingkungan yang singgahi mahasiswa. Lingkungan tersebut akan memberikan efek terhadap mahasiswa.

Kedua, sikap religius dan nilai keimanan. Nilai-nilai agama merupakan suatu proses yang harus dimasukkan di dalam hati agar jiwa tergerak untuk melakukan hal-hal berdasarkan ajaran-ajaran agama. Jika di hati sudah tertanam ajaran-ajaran agama tentunya kesadaran tersebut akan diteruskan secara utuh. Kesadaran tersebut akan mempengaruhi dan membentuk sikap mahasiswa dalam nilai-nilai agama yang sudah ditanamkannya di dalam dirinya. Melihat kondisi yang beragam dari kepribadian mahasiswa saat ini tentu ada kaitannya dengan keberadaan LDK di kampus, itu dikarenakan bahwa adanya Lembaga Dakwah Kampus ini sangat penting atas perubahan mahasiswa, apalagi banyak mahasiswa saat ini yang sudah salah mengambil arah jalan hidupnya sehingga berakibatnya akan terjerumus ke jalan yang salah. Hal ini bisa disebabkan oleh faktor yang selalu menyibukkan diri dan menyalahgunakan teknologi yang sudah sangat modern pada saat ini. Akan tetapi, dengan adanya kegiatankegiatan yang berbasis keislaman yang dilaksanakan oleh pihak LDK Al-Hayyan dapat membantu untuk mengubah akhlak dan perilaku mahasiswa.

Ketiga, sikap religius dalam keterampilan sosial. Ajaran-ajaran dalam agama tentunya memiliki tujuan untuk membimbing, mendorong untuk membuat dan memilih tindakan yang bermakna terhadap tindakan apa yang dilakukan. Nilai-nilai agama yang terkandung mempunyai peran yang sangat penting untuk mengembangkan etos. Fungsi lembaga dakwah 
kampus tentunya sebagai pusat gerakan dakwah di kampus. Bagaimanapun koordinasi yang terlibat perlu untuk melakukan strategi dakwah dalam perubahan bagi kader LDK maupun mahasiswa dengan dilakukannya kegiatan-kegiatan rutin yang dilaksanakan untuk perubahan perilaku terlebih dalam kepribadian mahasiswa. Sebelum mahasiswa mengambil arah jalan yang salah dalam dunianya dan akan mengakibatkan terjerumus ke jalan yang salah, kegiatan LDK hadir untuk memberikan perubahan sikap yang positif bagi mahasiswa.

Setiap lembaga maupun organisasi yang masih berada dalam perkembangan dan pembinaan seperti lembaga yang berada di kampus LDK Al-Hayyan yang mengembangkan kajian sesuai dengan ajaran-ajaran Alquran untuk meningkatkan dakwah Islami juga memiliki berbagai faktor pendukung dan faktor penghambat untuk terus mengembangkan lembaganya di kampus. Berdasarkan hasil pengamatan dan wawancara dengan pengurus LDK Al-Hayyan, di bawah ini adalah faktor pendukung dan faktor penghambat dalam pelaksanaan strategi komunikasi LDK Al-Hayyan:

1. Keberhasilan

a. Pengurus dan anggota LDK Al-Hayyan harus memiliki rasa tanggung jawab serta loyalitas agar tetap terus mengabdi dan melaksanakan kegiatan dakwah yang baik.

b. Adanya respon yang positif dari mahasiswa yang merupakan pengurus ataupun mahasiswa yang tidak masuk ke dalam keanggotaan LDK yang diberikan kepada pengurus yang telah melaksanakan kegiatan yang bermanfaat.

c. Mahasiswa menjadi rutin mengikuti kegiatan-kegiatan LDK Al-Hayyan

d. Mahasiswa menjadi antusias sholat berjamaah di mushollah kampus

e. Pengurus LDK Al-Hayyan harus memiliki potensi yang kuat.

f. LDK Al-hayyan mempunyai susunan jabatan dengan kapasitas sesuai dengan masingmasing bidang yang ada di lembaga.

2. Hambatan

Faktor penghambat yang merupakan faktor yang dapat membuat strategi dalam menjalankan kegiatan menjadi tidak baik. Adapun faktor penghambat yang dimiliki LDK AlHayyan adalah sebagai berikut :

a. Dana untuk melaksanakan kegiatan dakwah diperoleh sangat minim.

b. Kurangnya untuk bersosialisasi dari pengurus terhadap anggota LDK.

c. Kurangnya dalam membagi-bagi waktu untuk kegiatan dengan kesibukan pribadi.

d. Semangat dari anggota mulai menurun karena ada beberapa kader LDK Al-Hayyan yang masih kurang aktif dikarenakan adanya tugas-tugas kuliah sehingga tugas yang tidak bisa dilaksanakan diberikan kepada kader yang ada agar kegiatan tetap berjalan sesuai dengan rencana yang telah dibuat.

Dalam melaksanakan kegiatan-kegiatan LDK Al-Hayyan tentu tidak lepas dari faktor yang dapat mempengaruhinya, adapun faktor yang dimaksud adalah faktor pendukung dan faktor penghambat. Faktor pendukung yang dapat membuat kegiatan-kegiatan yang akan dilaksanakan berjalan sesuai dengan rencana yang sudah disepakati. Faktor penghambat adalah masalah yang timbul dari pelaksanaan kegiatan-kegiatan sehingga mengakibatkan kegiatan tersebut tidak berjalan dengan sempurna.

Faktor pendukung bagi LDK Al-Hayyan adanya rasa tanggung jawab dari pengurus yang ikut berpartisipasi untuk melancarkan kegiatan-kegiatan yang akan dilaksanakan oleh pihak LDK Al-Hayyan sehingga dapat memberikan nilai positif bagi mahasiswa-mahasiswa. Selain faktor pendukung yang dimiliki LDK Al-Hayyan, ada juga faktor penghambat yang dimiliki oleh pihak LDK dalam melaksanakan kegiatan yaitu kurangnya waktu untuk bersosialisasi terhadap 
anggota dikarenakan kesibukan yang dimiliki dari sebagian pengurus LDK.

Masalah yang menjadi faktor penghambat bagi LDK Al-Hayyan termasuk masalah yang sangat klasik seperti masalah dana yang terbatas dan kesibukan masing-masing dari pengurus, itu bisa saja diselesaikan dengan cara pengaturan jadwal kegiatan LDK Al-Hayyan, saling mengajak dan saling mendorong kepada pengurus agar timbulnya kesadaran untuk melaksanakan kegiatan-kegiatan keagamaan. Apabila tidak adanya faktor kesadaran dari dalam diri masing-masing, maka berbagai kegiatan yang akan diadakan akan menimbulkan moral pada aktivisnya akan menjadi terhambat. Solusi untuk faktor pendukung dan faktor penghambat harus ada pembinaan kemudian dikembangkan.

Kegiatan yang dilaksanakan oleh LDK Al-Hayyan ini sudah mendapatkan respon yang positif dari mahasiswa STMIK Budi Darma Medan maupun dari masyarakat luar yang ikut serta mengikuti kegiatan yang dilaksanakan LDK Al-Hayyan. Dengan dilaksanakannya kegiatan-kegiatan yang bertujuan untuk mengetahui, memahami dan memperdalam ajaranajaran Islam.

\section{Simpulan}

Berdasarkan dari data yang Penulis lakukan setelah melakukan penelitian pada LDK Al-Hayyan, maka dapat penulis tarik menjadi kesimpulan dari penelitian tersebut, yaitu:

1. Kondisi kepribadian Islam pada mahasiswa STMIK Budi Darma Medan memiliki keberagamaan yang berbeda-beda yang dilihat dari cara beribadah, perilaku dan cara berpakaian pada setiap diri mahasiswa. Hal tersebut disebabkan karena dari faktor lingkungan dan faktor pergaulan yang berbeda-beda mereka tempati.

2. Strategi komunikasi yang dilakukan oleh Lembaga Dakwah Kampus Al-Hayyan adalah melalui komunikasi antar personal dan komunikasi tidak langsung berupa melalui materi dan berdakwah melalui media yang masuk ke dalam bentuk kepedulian terhadap sesama pelaksanaan kegiatan-kegiatan yang dilakukan oleh LDK Al-Hayyan merupakan kegiatan keagamaan yang terkandung tentang ajaran-ajaran islam, kegiatan kepedulian terhadap sosial masyarakat.

3. Dalam pelaksanaan kegiatan-kegiatan yang menjadi strategi tentu adanya keberhasilan yang menjadi pendukung kegiatan dan ada pula hambatan yang menjadi penghambat dalam kegiatan tersebut, yaitu:

Keberhasilan dari kegiatan yang di capai adalah sebagai berikut:

a. Pengurus dan anggota LDK Al-Hayyan mempunyai rasa tanggung jawab yang lebih.

b. Adanya respon yang positif dan semangat dari mahasiswa yang diberikan kepada semua kalangan pengurus LDK Al-Hayyan.

c. Pengurus LDK Al-Hayyan memiliki potensi yang lebih.

d. LDK Al-Hayyan memiliki susunan struktur anggota keorganisasian dan masing-masing diberikan tugas-tugas dengan kemampuan dan bidangnya.

Sedangkan penghambat dari kegiatan yang di lakukan adalah sebagai berikut:

a. Dana yang diperoleh masih sangat minim dalam kegiatan yang dilaksanakan LDK AlHayyan.

b. Kurangnya waktu untuk bersosialisasi yang lebih dari pengurus kepada anggota dikarenakan kesibukan pribadi yang dimiliki.

c. Semangat dari anggota LDK Al-Hayyan mulai turun karena terdapat beberapa anggota yang masih kurang aktif. 
KOMUNIKA: Jurnal Dakwah dan Komunikasi, 14 (1), April 2020

Fitri Aisyah Ritonga; Ahmad Tamrin Sikumbang; Zainun (Membentuk Kepribadian Islam melalui...)

\section{Saran}

Berdasarkan simpulan di atas yang telah diperoleh dari peneliti, maka terdapat beberapa saran agar pengamalan agama yang dimiliki mahasiswa meningkat yang peneliti ajukan sebagai berikut:

1. Bagi pengurus Lembaga Dakwah Kampus Al-Hayyan

a. Harus tetap semangat terus untuk mengajarkan dan menyebarkan nilai-nilai ajaran Islam di kampus STMIK Budi Darma Medan agar bisa mewujudkan mahasiswa yang paham dan sadar akan hal-hal yang terkandung dalam nilai-nilai ajaran Islam, bisa mengajak dan melahirkan generasi anggota baru untuk masuk ke dalam Lembaga Dakwah Kampus.

b. Bisa lebih mengoptimalkan strategi dakwah yang bisa memikat sesuai dengan keadaan lingkungan kampus agar bisa mengajak dan menjalankan kegiatan seharihari mahasiswa sesuai dengan nilai ajaran Islam yang baik dan benar.

2. Bagi mahasiswa

Buat mahasiswa yang tidak bergabung dalam LDK Al-Hayyan sekiranya tetap semangat untuk terus berpartisipasi ke dalam kegiatan yang dilaksanakan LDK Al-Hayyan, baik itu dalam kegiatan kajian ataupun dalam kegiatan kepedulian untuk berbagi agar pengamalan agama terus meningkat.

3. Bagi pembaca

Bagi pembaca agar terus meningkatkan pengamalan agama, tidak hanya melalui ibadah untuk diri sendiri tetapi untuk sesama yang lain agar menjalin tali persaudaraan dalam kehidupan. 
KOMUNIKA: Jurnal Dakwah dan Komunikasi, 14 (1), April 2020

Fitri Aisyah Ritonga; Ahmad Tamrin Sikumbang; Zainun (Membentuk Kepribadian Islam melalui...)

\section{DAFTAR PUSTAKA}

Abdullah, Adil Fathi. (2014). 20 Tips Membangun Kepribadian Islam. Jakarta: Gema Insani

Afrizal. (2016). Metode Penelitian Kualitatif Sebuah Upaya Mendukung Penggunaan Penelitian Kualitatif Dalam Berbagai Disiplin IImu. Jakarta: Raja Grafindo Persada.

Agency, Beranda, Mengajarkan Kejujuran Itu Tidak Susah, Bandung: Elex Media, 2015

Agung, J. (2014). Renungan Bagi Aktivis Dakwah Kampus. Bandung: Quanta.

Alam, L. (2016). Internalisasi Nilai-Nilai Pendidikan Islam dalam Perguruan Tinggi Umum Melalui Lembaga Dakwah Kampus. Istawa: Jurnal Pendidikan Islam. https://doi.org/10.24269/ ijpi.v1i2.171

Al-Hasyimi, Muhammad, Kepribadian Wanita Muslimah, Jakarta: Qisthi Press, 2001.

Al-Jumhuri, Muhammad Asroruddin. (2015). Belajar Aqidah Akhlak, Yogyakarta: Deepublish.

Alim, M. (2011). Pendidikan Agama Islam. Bandung: PT. Remaja Rosdakarya.

Angkat, D. (2020, Februari 21). Koordinator HUMAS dan Syiar LDK Al-Hayyan STMIK Budi Darma.

Apriliani, A. (2020, Februari 24). Sekretaris Dana dan Usaha LDK Al-Hayyan STMIK Budi Darma.

Arianto, D. (2020, Februari 24). Anggota LDK Al-Hayyan STMIK Budi Darma.

Cangara, H. (2013). Perencanaan dan Strategi Komunikasi. Jakarta: Rajawali Pers.

Dewi, S. (2020, Februari 24). Mahasiswi STMIK Budi Darma.

Faozin, Muh (2009). Pemahaman Tingkah Laku. Jakarta: PT. Rineka Cipta

Liliweri, Alo. (2010). Strategi Komunikasi Masyarakat. Yogyakarta: LKis Yogyakarta.

Majid, A. (2012). Belajar dan Pembelajaran Pendidikan Agama Islam. Bandung: Remaja Rosydakarya.

Masripah. (2007). Urgensi Internalisasi Pendidikan Aqidah Akhlak Bagi Generasi Muda. Jurnal Pendidikan Universitas Garut, 52-61.

Nata, A. (2010). IImu Pendidikan Islam. Jakarta: Prenada.

Prayogi, A. (2019). Masuk Dan Berkembangnya Gerakan Tarbiyah, Studi Kasus: Gerakan Dakwah Kampus Di Institut Teknologi Bandung. Sindang: Jurnal Pendidikan Sejarah Dan Kajian Sejarah. https://doi.org/10.31540/sdg.v1i1.204

Pirol, Abdul. (2018). Komunikasi dan Dakwah Islam. Yogyakarta: Deepublish.

Rahmawati, L. (2020, Februari 21). Bidang Kaderisasi LDK Al-Hayyan STMIK Budi Darma Medan.

Silviana, Irene. (2020). Komunikasi Organisasi. Surabaya: Scopindo Media Pustaka.

Saddam Husein, N. K. A. P. (2018). Pembinaan Akhlak Mulia Mahasiswa dalam Lembaga Dakwah Kampus (LDK) Al-Izzah lain Ambon. Al-Iltizam: Jurnal Pendidikan Agama Islam. https://doi.org/10.33477/alt.v3i1.417

Samsu, S., \& Mansur, M. (2019). Manajemen Dakwah Lembaga Dakwah Kampus Unit Pengkajian Mahasiswa Islam (LDK-UPMI) IAIN Kendari. al-munzir. https://doi.org/10.31332/ am.v12i1.1325

Setiawan, A. I. (2015). Efektivitas Dakwah Fi'ah: Studi Model Dakwah pada Lembaga Dakwah Kampus. Jurnal Ilmu Dakwah. https://doi.org/10.15575/jid.v5i2.378

Sukarta, S. (2018). Internalisasi Nilai-Nilai Dakwah Multikultural dalam Pembelajaran Al-Islam di Universitas Muhammadiyah Mataram. Al-I'lam: Jurnal Komunikasi Dan Penyiaran Islam. https://doi.org/10.31764/jail.v1i2.229 
KOMUNIKA: Jurnal Dakwah dan Komunikasi, 14 (1), April 2020

Fitri Aisyah Ritonga; Ahmad Tamrin Sikumbang; Zainun (Membentuk Kepribadian Islam melalui...)

Sulaiman, Umar, I Am A Moeslim, Yogyakarta: Mirqat, 2000.

Savitri, Intan, Belajar Jujur, Yogyakarta: Andi, 2010

White, Jerry, Kejujuran, Moral dan Hati Nurani, Jakarta: Grafindo Persada, 2011.

Wilcox, Lynn. (2018). Psikologi Kepribadian. Yogyakarta: IRCiSoD

Widyarini, Nilam. (2013). Membangun Hubungan Antar Manusia, Jakarta: Elex Media.

Wildan, M. (2015). Gerakan Islam Kampus: Sejarah dan Dinamika Gerakan Mahasiswa Muslim. In Sejarah Kebudayaan Islam Indonesia Jilid 3.

Yasin, A. (2004). Dasar-Dasar Ilmu Pendidikan

Yusuf, A. M. (2015). Assesment dan Evaluasi Pendidikan Jakarta Prenadamedia Kencana. 